[Vicino Oriente XXI (2017), pp. 257-263]

\title{
UNPUBLISHED ISLAMIC BRONZE CAULDRONS FROM PRIVATE COLLECTIONS: TWO EARLY AND ONE VERY LATE SPECIMENS
}

\author{
Valentina Laviola - ‘Alma Mater Studiorum’ University of Bologna
}

\begin{abstract}
Along with stirrups, cauldrons embody the cultural influence played by nomadic populations on early Islamic metalwork. Not much can be added about a largely investigated class of objects, except for some unpublished items (two from Herat, one from Central Asia) from private collections.
\end{abstract}

Keywords: cauldrons; Islamic metalwork; Herat; Central Asia; nomadic populations

What else can be said about a largely investigated class of metalwork such that of Islamic cauldrons is? Apparently nothing, if not letting speak specimens hidden so far in private collections. ${ }^{1}$ Much has been written searching the origin of cauldrons in Caucasus, Khurasan or Transoxiana, and about the evolution of the different existing models. ${ }^{2}$ This brief note will be in no way the occasion to reopen the discussion about theories elaborated by far more experienced scholars. It will just uncover three unpublished cauldrons to see confirmed a continuity extending from early specimens to modern imitations.

\section{TWO CAULDRONS FROM HERAT (figs. 1-2)}

In 2014, the author had the chance to be admitted to a small private collection in Herat, which gathers especially Islamic metalwork: among these, two cauldrons, said to come from the city itself, drew the attention. Both belong to the hemispherical model, the most spread in the Khurasan region; measures are on average and the condition is fair. The dark grey surface shows a whitish patina on some areas; traces of verdigris appear inside one of the vessels (no. 2, fig. 2).

The first cauldron (fig. 1) is smaller ${ }^{3}$ and gentler in its plain morphology and delicate decoration. The rim is quite short, while flanges are well developed ending in pointed corners, one of which is broken. The pouring channel is completely flat and defined by two raised mouldings, bearing some incisions reminding of a zigzag motif. Eight pairs of nicks run on the edge of three flanges; four pairs dispose on sides of the spout, while a continuous series of nicks runs along the pouring margin. Fixed vertically raised handles are cast on their top in a pronounced three-petalled flower; two horizontal lines are engraved on each side of handle's arch, as an ornamental strip.

The decoration is very simple, but designed on the base of symmetry and regularity. The modest motifs probably indicate an early date, and being typical of stone, they could

1 I express my gratitude to the collectors, who consented me to study and publish the cauldrons. I also wish to thank Serenella Mancini, who took pictures of the cauldron in Rome.

2 See in particular Scerrato 1964, 687-696 (2 ${ }^{\text {nd }}$ ed. 2014, 1000-1008); Allan 1976, 190-196; and more recently Ivanov 1996a; 1996b; 2003. A very small cauldron, whose sizes lead to imagine a use different from cooking, was found in the excavation of Istakhr (see Schmidt 1939, 118, fig. 84). The presence of such a metalwork in Fars could surprise, but it would be worthy to remind that the site was on a major commercial way, so that the cauldron could have been imported as many of the retrieved ceramic items were (see Fontana et al. 2016, 89).

$3 \varnothing \max 49 \mathrm{~cm}$, Ø without flanges $36 \mathrm{~cm}$, h. max $31 \mathrm{~cm}$, h. without handles $22 \mathrm{~cm}$.

ISSN 0393-0300

e-ISSN 2532-5159 
also be claimed in support to the Iranian origin of hemispherical cauldrons, since a possible prototype in stone was found in Nishapur and dated by Wilkinson to the $9^{\text {th }}$ century. ${ }^{4}$

The second cauldron (fig. 2) is larger ${ }^{5}$ and bolder in its shape. One foot is detached, but still preserved; the back flange looks significantly smaller than others do. A great prominence is given to the pouring one, which protrudes with a large, almost rectangular perimeter. A fillet covers the sunken pouring channel at both its ends. Groups of three nicks appear on the edge of the back flange and in a continuous series on the pouring one. Lateral flanges, instead, are undecorated. The strong handles are topped by a stylized squarish element.

Similar cauldrons from the region are known: one of them is currently preserved in the Herat National Museum; ${ }^{6}$ other two, once part of the now lost Kabul National Museum's collection, came from Maimana. ${ }^{7}$ Herat, close to the present-day Afghan northern border, may have easily represented a place of interaction with populations from Central Asian steppes. Cauldrons, in fact, clearly designed to stand over an open fire, most likely originated in the nomadic context. ${ }^{8}$

\section{A CAULDRON IN ROME (figs. 3-8)}

An old private collection in Rome houses a hemispherical cauldron coming from Central Asia (fig. 3) ${ }^{9}$ The object is in a good state of preservation; a small patch was added to the inner bowl. The colour is a homogenous brown, with few greenish areas inside the vessel where the surface looks scratched, presumably because of use. The inner surface is polished, while the outer one is quite raw. The pouring flange is slightly smaller. Threepetalled flowers top the fixed handles (fig. 4).

Lateral flanges are thematically paired from a decorative point of view as the back flange is with the pouring one. The latter, defined by two mouldings on high relief, is flat: a grill motif made of crossing strips decorates the spout, flanked by two zoomorphic roundels (fig. 5). ${ }^{10} \mathrm{~A}$ bird portrayed on the profile, with turned back head and the beak pointing to its body, appears in each one of them. In the general arrangement, the bodies of the two birds are affronted.

The back flange bears a trapezoidal cartouche with concave short sides: it frames a kufic pseudo-inscription (fig. 6). Letters dispose on two lines; some of them are identifiable: a pair of hastae, a mirrored $w \bar{a} w$, a knotted group, a possible $d \bar{a} l$ and a $l \bar{a} m$. Most of letters show rounded apices, but the lower terminal in the final lām is sharply concave-cut, in

4 See Wilkinson 1944, 288. Taken for good the chronology proposed by Wilkinson, the stone cauldron would precede copper alloy items (see Allan 1976, 195).

$5 \varnothing$ max $58 \mathrm{~cm}, \varnothing$ without flanges $46 \mathrm{~cm}$, h. max $31 \mathrm{~cm}$, h. without handles $20.5 \mathrm{~cm}$.

6 Inv. No. HNM 03.10.86e (see Müller-Wiener 2016, Cat. No. M32, fig. 19). The Museum’s collection nowadays counts many cauldrons, attesting also different models.

7 See Scerrato 1964, 687, nos. 6-7, figs. 18-22, pls. IX-X ( $2^{\text {nd }}$ ed. 2014, 1000, figs. 18-22); Allan 1976, 680. See also V. Laviola, Islamic Metalwork from Afghanistan (9th-13th c.). The Italian Archaeological Mission Archives, Leiden 2018, § 2.2. At the time of finding cauldrons still preserved a soot crust on their bottoms.

8 See Scerrato 1964, 688-689 ( $2^{\text {nd }}$ ed. 2014, 1002).

$9 \varnothing \max 44.5 \mathrm{~cm}$, Ø without flanges $33.6 \mathrm{~cm}$, h. $\max 21 \mathrm{~cm}$, h. without handles $14 \mathrm{~cm}$.

10 The grill motif could be a reminiscence of a real filter, which used to be applied on the spout of vessels related to liquids such as ewers as well. 
contrast with the bilobed terminal of the previous letter, to let space for the vegetal motif that fills the end of the cartouche. The inscription makes no sense as a whole. Two roundels flank the cartouche, each one including a bird that differs from the above-mentioned ones in the erect head and the big beak.

The decoration of the lateral flanges is limited to elongated triangular cartouches in the corners (figs. 7-8). Their peculiar shape forces letters to lay one down the other, generating a tight confused composition that makes difficult even to distinguish them. $W \bar{a} w$-shaped letters, some of which are mirrored, show pointed sloping bodies and terminals with apices: a general tendency to the vegetal motif is evident. As far as it is possible to understand, letters look disposed outward, but no meaningful word can be recognised. Furthermore, the script diverges from that observed on the back flange. ${ }^{11}$

The cauldron is standard as far as morphology and cast details are concerned; its decoration instead reveals some inaccuracies, maybe due to an inexpert hand. Geometrical lines defining cartouches often end overlapping each other; cartouches on the lateral flanges are inexplicably asymmetrical in size. The decoration is partially executed in champlevé (the birds and the grill motif), partially engraved with a thin single or double line (the pseudo-epigraphical cartouches and birds' details). On birds' body is well visible the mark where the compass point stood to trace the roundel (fig. 6).

The two pairs of birds differ from each other. Moreover, birds are hardly ever attested on cauldrons: ${ }^{12}$ running or hunting quadrupeds generally occur, along with vegetal, geometrical or even symbolic motifs. Still, some of birds' features such the up-ended tail(s), the neck collar, the wing shape attest that the artisan had in mind medieval models.

The epigraphical cartouche on the back flange occupies the correct position traditionally held on cauldrons, echoing the trapezoidal shape of the flange itself. Usually artisan's signatures appears there, ${ }^{13}$ while good wishing terms are rare. ${ }^{14}$ No element in the pseudoinscription can suggest it was meant to fake a signature, while the hastae and wāws point to a benedictory expression. The presence of mirrored letters betrays that whoever wrote them had only a vague idea of what he was handling.

Finally, the decoration on cauldrons usually disposes toward the vessel inside. Awkwardly, in this case, the two pairs of roundels look toward the outside, careless of the fact that it is inconsistent with cartouche direction.

11 Considered the difference between the two scripts, it cannot be excluded that the pseudo-inscriptions on lateral flanges and that on the back flange were executed in different moments.

12 Birds (and beasts) appear on a $12^{\text {th }}$ century cauldron from the Hermitage Museum of Saint Petersburgh signed by Maḥmūd al-Qazwīnī (see Ivanov 2003, 481).

13 Cauldrons seem to have been signed more frequently than other classes of metalwork: the reason could be the expertise necessary to create such an object that led artisans to mark their works (see Scerrato 1965, 231 [2 ${ }^{\text {nd }}$ ed. 2014, 1054]).

14 An interesting example can be found in a small cauldron in the Museo Nazionale d'Arte Orientale 'G. Tucci' of Rome (Inv. No. 5862): a benedictory term repeats on three of its flanges. The cauldron comes from Ghazni and was donated to the Museum by Umberto Scerrato in 1970. 


\section{CONCLUSIVE REMARKS}

Anthropological studies led in Daghestan (north Caucasus) - one of cauldrons' production areas - report that these objects were involved in rituals and held a relevant position in the domestic context, as symbols of the wife entering her husband house and family. These vessels embodied the hearth; in fact, they were employed in cooking wedding and funeral banquets, then being part of any important event. Their remarkable value (even used to pay tributes) easily led families to preserve them. ${ }^{15}$ All these reasons have fostered a continuity of production across the centuries and a strongly conservative style, which consent today to have at disposal examples so different and chronologically far as those presented here.

The barely undecorated cauldrons from Herat probably represent the ancient production of Khurasan: two early specimens datable at the latest within the $12^{\text {th }}$ century.

The already mentioned peculiarities, along with the discrepancy in pseudo-epigraphical cartouches, make difficult to date the cauldron in Rome. The overall opinion one can obtain is that the object was inspired to the golden age Islamic production but incapable to meet the expectancies on the ground of quality. Nevertheless, its bizarre decoration is far from the scripts and zoomorphic figures employed in later metalwork as well, so that it cannot be compared to Timurid or Safavid works. ${ }^{16}$ Then, reasons are enough to risk in proposing a $19^{\text {th }}$ century dating: most likely, its manufacturing meant to imitate medieval specimens, but a deceiving intent is to exclude, since only a fake artisan's signature would have enhanced the object value.

\section{REFERENCES}

Allan, J.W.

1976 The Metalworking Industry in Iran in the Early Islamic Period, PhD thesis, Oxford University, Oxford 1976, ora.ox.ac.uk/objects/uuid:278c6978-9421-46af-af61a062a2044591.

Fontana, M.V. - Asadi, A.A. - Rugiadi, M. - Felici, A.C. - Fusaro, A. - Mancini, S.

2016 Estakhr Project - Third Preliminary Report of the Joint Mission of the Iranian Center for Archaeological Research, The Parsa-Pasargadae Research Foundation and the Sapienza University of Rome, Italy: Vicino Oriente XX (2016), pp. 75-98.

IVANOV, A.

1996a 118. Cauldron: V. Loukonine - A. IvAnov (eds.), Lost Treasures of Persia. Persian Art in the Hermitage Museum, Washington D.C. 1996, p. 138.

1996 b 119. Cauldron: V. LoukOnine - A. IvANov (eds.), Lost Treasures of Persia. Persian Art in the Hermitage Museum, Washington D.C. 1996, p. 139.

2003 Bronze cauldron with the name of Mahmūd ibn al-Hasan (?) al-Qazwīnī: M.V. FonTANA B. Genito (eds.), Studi in onore di Umberto Scerrato per il suo settantacinquesimo compleanno, Università degli Studi di Napoli "L'Orientale", Dipartimento di Studi Asiatici (Series Minor 65), 2 vols., Napoli 2003, vol. 2, pp. 479-484.

15 See Scerrato 1965, 231 ( $2^{\text {nd }}$ ed. 2014, 1054) and previous bibliography.

16 For an extensive overview on late Iranian metalwork, see Ivanov 2014. 
2014 The State Hermitage Museum. Iranian Copper and Bronze (Brass). Artefacts from the Second Half of the 14th to the Mid-18 ${ }^{\text {th }}$ Century. Catalogue of the Collection, St. Petersburgh 2014.

MÜLLER-WIENER, M.

2016 Metalwork from the 10th to the 13th century: U. FrANKE - M. MÜLLER-WIENER (eds.), Ancient Herat, Vol. 3. Herat Through Time. The Collections of Herat Museum and SCERRATO, U. Archive, Stuttgart 2016, pp. 89-138.

1964 Oggetti metallici di età islamica in Afghanistan. II: Il ripostiglio di Maimana: Annali dell'Istituto Orientale di Napoli N.S. 14.2 (1964), pp. 673-714 ( ${ }^{\text {nd }}$ ed.: M.V. FonTANA [ed.], Umberto Scerrato. Saggi inediti e opera minora [Quaderni di Vicino Oriente VII], Roma 2014, pp. 989-1052).

1965 Una caldaia iranica di bronzo del Museé des Antiquités di Algeri: Annali dell'Istituto Orientale di Napoli N.S. 15 (1965), pp. 229-236 (2nd ed.: M.V. FonTANA [ed.], Umberto Scerrato. Saggi inediti e opera minora [Quaderni di Vicino Oriente VII], Roma 2014, pp. 1053-1064).

SCHMIDT, E.F.

1939 The Treasury of Persepolis and Other Discoveries in the Homeland of the Achaemenians (Oriental Institute Communications 21), Chicago 1939.

WILKINSON, C.K.

1944 Heating and Cooking in Nishapur: The Metropolitan Museum of Art Bulletin 10 (1944), pp. 282-291. 


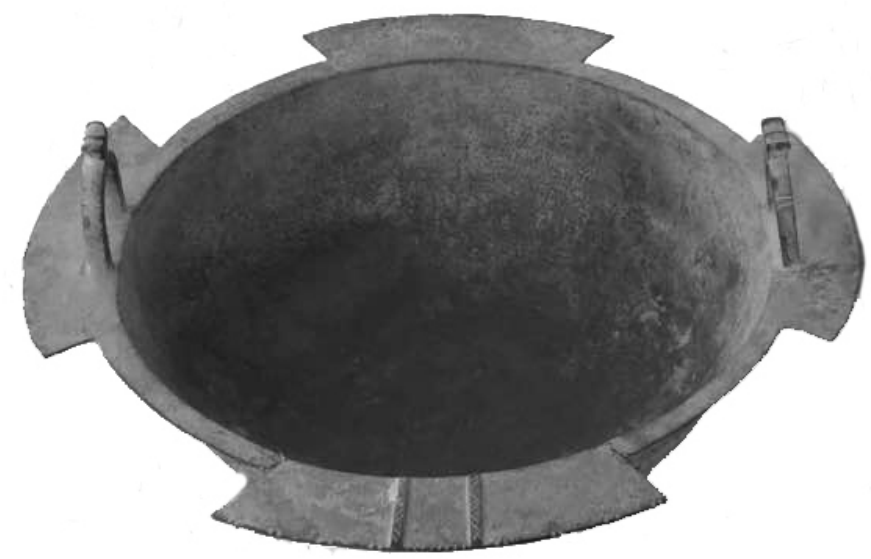

Fig. 1 - Herat cauldron no. 1 (photo by Valentina Laviola).

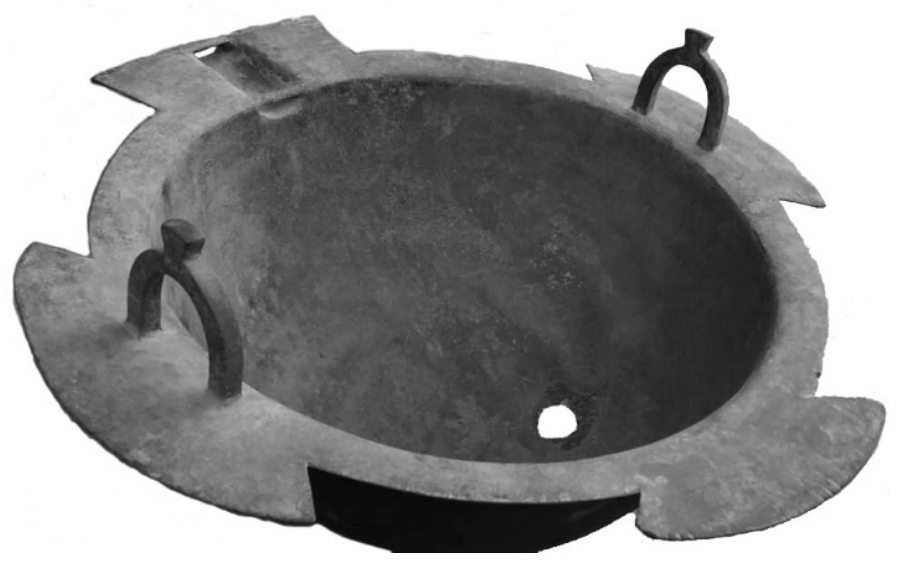

Fig. 2 - Herat cauldron no. 2 (photo by Valentina Laviola). 


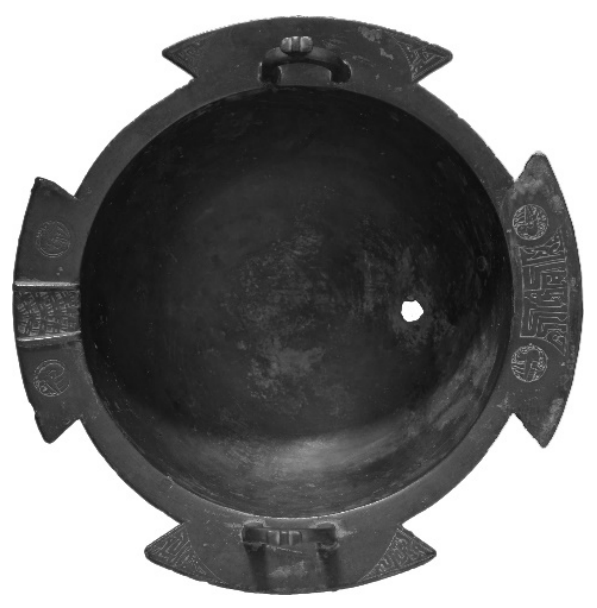

Fig. 3 - Rome cauldron, upper view (photo by Serenella Mancini).

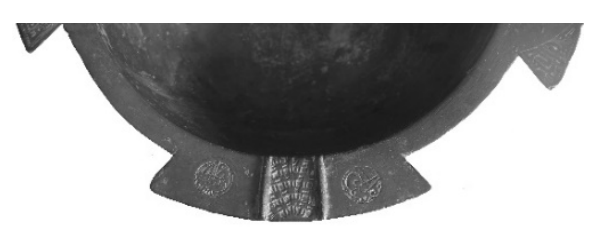

Fig. 5 - Rome cauldron, pouring flange (photo by Serenella Mancini).

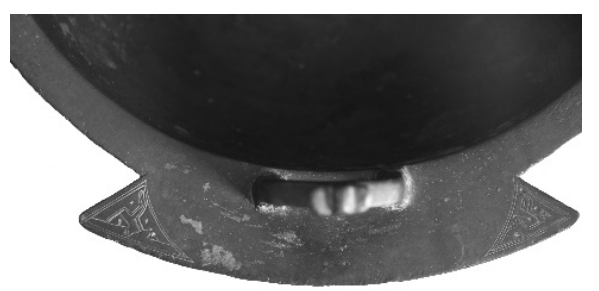

Fig. 7 - Rome cauldron, left lateral flange (photo by Serenella Mancini).

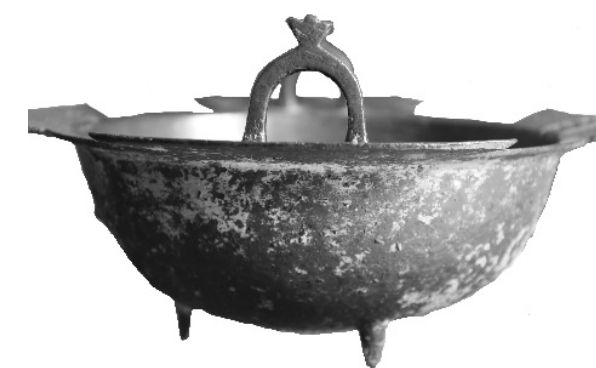

Fig. 4 - Rome cauldron, profile (photo by Serenella Mancini).



Fig. 6 - Rome cauldron, back flange (photo by Serenella Mancini).

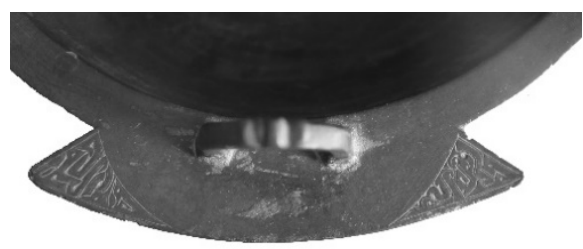

Fig. 8 - Rome cauldron, right lateral flange (photo by Serenella Mancini). 